\title{
Fluid Matters in Choosing Antihypertensive Therapy: A Hypothesis That the Data Speak Volumes
}

\author{
Robert P. Blankfield, MD, MS
}

Assuming that blood pressure is lowered equivalently, diuretics are more effective than angiotensinconverting enzyme inhibitors (ACEIs), calcium channel blockers (CCBs), and $\alpha$-adrenergic receptor blockers $(\alpha$-blockers) at preventing heart failure, and they are more effective than ACEIs and $\alpha$-blockers at preventing strokes. Compared with $\beta$-adrenergic receptor blockers ( $\beta$-blockers) and ACEIs, CCBs are less effective at reducing myocardial infarcts and heart failure. There is currently no conceptual framework by which to organize data indicating that some antihypertensive medications are better than others at preventing cardiovascular diseases. The thesis of this article is that the fluid reduction or fluid retention attributable to antihypertensive medications, either alone or in combination, provides a basis for ranking these medications. Diuretics have a theoretical advantage compared with other antihypertensive medications because they reduce total body fluid more than other agents. Therefore, they are the preferred drugs for treating hypertension. The other antihypertensive agents that promote fluid reduction, ACEIs and angiotensin receptor blockers (ARBs), are next in preference, ranking a close second to diuretics. Because $\beta$-blockers have a neutral effect on total body fluid, they rank on a third tier of preference, after ACEIs and ARBs. CCBs and $\alpha$-blockers are the least preferred medications for treating hypertension because they promote fluid retention. (J Am Board Fam Pract 2005;18:113-24.)

Provided that blood pressure is lowered comparably, diuretics have been demonstrated to be more effective than angiotensin-converting enzyme inhibitors (ACEIs), calcium channel blockers (CCBs), and $\alpha$-adrenergic receptor blockers ( $\alpha$-blockers) at preventing heart failure, and diuretics have been found to be more effective than ACEIs and $\alpha$-blockers at preventing stokes. ${ }^{1-5}$ Diuretics offer no advantage over ACEIs, CCBs, or $\alpha$-blockers in preventing fatal coronary heart disease, preventing nonfatal myocardial infarcts, or lowering all-cause mortality, and diuretics offer no advantage over CCBs in preventing strokes. ${ }^{3,4}$ Compared with $\beta$-adrenergic receptor blockers ( $\beta$-blockers) and ACEIs, CCBs are less effective at reducing myocardial infarcts and heart failure. ${ }^{1,2}$

Although the preponderance of the evidence favors using diuretics as first line pharmacological therapy for the treatment of hypertension, ${ }^{6}$ the

Submitted, revised, 13 December 2004.

From the Department of Family Medicine, Case Western Reserve University, School of Medicine, Cleveland, OH. Address correspondence to Robert P. Blankfield, MD, MS, Berea Health Center, University Hospitals Primary Care Physician Practice, 201 Front Street, Suite 101, Berea, OH 44017 (e-mail: blankfield@adelphia.net). research data do not uniformly support this conclusion. The Second Australian National Blood Pressure (ANBP2) study demonstrated that, particularly in men, there were fewer cardiovascular events and fewer deaths from any cause in the group treated with ACEIs than in the group treated with hydrochlorothiazide (HCTZ). ${ }^{7}$ The favorable results for the ACEI in ANBP2 may reflect, in part, the predominance of white persons in the study population. Several studies have documented that the nondihydropyridine CCBs diltiazem and verapamil are equivalent to, and in some instances better than, diuretics and $\beta$-blockers in preventing some cardiovascular diseases. ${ }^{8-10}$ The second Swedish Trial in Old Patients with Hypertension (STOP-Hypertension-2) trial found no difference in long-term cardiovascular outcomes between subjects taking diuretics and $\beta$-blockers and subjects taking ACEIs and CCBs. ${ }^{11}$ The Captopril Prevention Project (CAPPP) compared captopril with diuretics and $\beta$-blockers and found that subjects treated with captopril were less likely to die from cardiovascular causes, but subjects in the captopril group were more likely to develop strokes. ${ }^{12}$ One might argue that $\beta$-blockers potentially di- 
luted the benefit of the diuretics in the STOPHypertension-2 and CAPPP trials, but in the Metoprolol Atherosclerosis Prevention in Hypertension (MAPHY) study, metoprolol was found to be superior to diuretics in terms of preventing sudden cardiovascular deaths. ${ }^{13}$

Of course, there are limitations in comparing the results of different antihypertensive trials. One limitation is that demographic differences such as age, gender, race, and ethnicity may confound the comparisons. Another limitation is that not all antihypertensive trials achieved equivalency in blood pressure reduction. For example, subjects in the Antihypertensive and Lipid-Lowering Treatment to Prevent Heart Attack (ALLHAT) study assigned to diuretic treatment had lower systolic blood pressures than subjects assigned to ACEI, CCB, or $\alpha$-blocker treatment, and subjects in the CCB group had lower diastolic blood pressures than subjects in the diuretic group. ${ }^{3,4}$ Even though the ALLHAT investigators made appropriate adjustments for the differences in blood pressures, these differences cloud the interpretation of the results. ${ }^{14}$

This article proposes that, apart from blood pressure lowering itself, the fluid reduction or fluid retention property of each antihypertensive medication helps explain its relative merit in preventing cardiovascular diseases. The benefit of diuretics compared with other antihypertensive medications lies in the ability of diuretics to lessen total body fluid-total body fluid being the sum of the intravascular fluid, the intracellular fluid, the interstitial fluid, and fluid that is third-spaced (pleural effusions or ascites). That ACEIs are sometimes superior to diuretics in terms of cardiovascular outcomes lies in the fluid reduction properties of ACEIs. On the other hand, compared with diuretics, $\beta$-blockers, ACEIs, and clonidine, the relative inferiority of CCBs in reducing myocardial infarcts and heart failure ${ }^{1}$ is the result of fluid retention. Finally, nondihydropyridine CCBs result in less fluid retention than do dihydropyridine CCBs. This may explain why some studies found no cardiovascular outcome differences when nondihydropyridine CCBs were compared with diuretics and $\beta$-blockers. This article will use the term "diuretic" to refer to thiazide medications such as HCTZ or chlorthalidone.

There is no method to directly and readily measure total body fluid. Weight gain or loss is used as a surrogate marker for total body fluid increases or decreases. Based on the presence or absence of leg edema, it is possible to gauge whether the amount of interstitial fluid is increased or not. Based on the presence or absence of jugular venous distension, hepatojugular reflux, or an S3 or S4 cardiac murmur, it is possible to gauge whether the amount of intravascular fluid is increased or not, and based on the presence or absence of ascites or a pleural effusion, it is possible to gauge whether fluid is third-spaced or not. In general, if there is increased interstitial fluid, increased intravascular fluid, or increased third-spaced fluid, then there is increased total body fluid.

If total body fluid determines the relative merits of antihypertensive medications, it is unclear why, but intravascular volume is probably a factor. When there is excess interstitial fluid in the form of leg edema, increased cardiovascular pathology may result from repetitive, transient changes in the fluid volume of the intravascular compartment that results from fluid shifting to dependent parts of the body, via the blood vessels and lymphatics, depending on whether people are recumbent or upright.

Table 1 lists a number of different antihypertensive medications and the rates of edema that have been reported with each one. Only trials involving hypertensive subjects without diabetes are included.

\section{Calcium Channel Blockers}

Leg edema is a common dose- dependent side effect of the CCBs. Edema formation occurs even though CCBs increase renal sodium excretion (natriuresis). ${ }^{15,16}$ In the case of nifedipine, the edema occurs simultaneously with the natriuresis. ${ }^{17}$

CCBs increase renal blood flow by selectively dilating the renal afferent arterioles, thereby resulting in natriuresis and diuresis. ${ }^{18}$ The initial diuretic and natriuretic effects of most CCBs probably persist with long-term usage, ${ }^{19,20}$ but the natriuresis resulting from nifedipine may be transient. ${ }^{21}$

Edema occurs with CCBs because of vasodilation in the distal arterioles, thereby leading to increased intravascular capillary pressures and increased venous pressures, at least in the lower extremities, ${ }^{22}$ and eventually leakage of fluid into the extracellular space.

In placebo-controlled studies, the rate of edema was $11 \%$ in a group treated with nifedipine, $14 \%$ in 


\begin{tabular}{|c|c|c|c|}
\hline $\begin{array}{l}\text { Medication } \\
\text { Reference }\end{array}$ & Total Daily Dose (mg) & Sample Size & Edema (\%) \\
\hline \multicolumn{4}{|c|}{ Dihydropyridine Calcium Channel Blockers } \\
\hline \multicolumn{4}{|l|}{ Amlodipine } \\
\hline Koenig, $1993^{30}$ & $5-10$ & 59 & 1.7 \\
\hline Frishman et al, $1995^{31}$ & 2.5 & 82 & 3.8 \\
\hline Kuschnir et a., $1996^{32}$ & 5 & 77 & 16.9 \\
\hline Corea et al, $1996^{33}$ & 5 & 84 & 3.6 \\
\hline Corea et al, $1996^{33}$ & 10 & 28 & 14.3 \\
\hline Messerli et al, $2000^{29}$ & 5 & 144 & 15 \\
\hline Messerli et al, $2000^{29}$ & 10 & 144 & 32 \\
\hline Kloner et al, $2001^{34}$ & $5-10$ & 127 & 22.1 \\
\hline \multicolumn{4}{|l|}{ Felodipine } \\
\hline Freeling et al, $1987^{35}$ & $2.5-10$ & 32 & 28.1 \\
\hline Dahlof and Hosie, $1990^{36}$ & 10 & 53 & 18.9 \\
\hline Hammond and Cutler, $1993^{37}$ & $5-10$ & 71 & 29.6 \\
\hline Koenig, $1993^{30}$ & $5-10$ & 59 & 0.0 \\
\hline Fagan et al, $1994^{26}$ & $5-10$ & 137 & 12.4 \\
\hline Goldberg et al, $1995^{24}$ & Unspecified & 43 & 14.0 \\
\hline Gradman et al, $1997^{38}$ & $2.5-10$ & 176 & 10.8 \\
\hline Schloze et al, $1999^{39}$ & $5-10$ & 84 & 7.1 \\
\hline \multicolumn{4}{|l|}{ Isradipine } \\
\hline Hammond and Cutler, $1993^{37}$ & $5-10$ & 72 & 13.9 \\
\hline Eisner et al, $1991^{40}$ & $2.5-10$ & 78 & 7.7 \\
\hline \multicolumn{4}{|l|}{ Lacdipine } \\
\hline UK Lacdipine, $1991^{43}$ & 4 & 268 & 6.0 \\
\hline \multicolumn{4}{|l|}{ Nicardipine } \\
\hline Gradman et al, $1992^{41}$ & 45 & 73 & 8.2 \\
\hline Gradman et al, $1992^{41}$ & 60 & 73 & 15.1 \\
\hline \multicolumn{4}{|l|}{ Nifedipine } \\
\hline Daniels and Opie, $1986^{23}$ & 40 & 35 & 11.4 \\
\hline Heagerty et al, $1988^{25}$ & $20-40$ & 210 & 12.4 \\
\hline Fagan et al, $1994^{26}$ & $30-90$ & 140 & 20.0 \\
\hline Steiner and Pauly, $1994^{27}$ & 40 & 55 & 12.7 \\
\hline Brown et al, $2000^{28}$ & $30-60$ & 3,157 & 28.4 \\
\hline Messerli et al, 200129 & 30 & 130 & 5.4 \\
\hline Messerli et al, $2001^{29}$ & 60 & 129 & 22.3 \\
\hline \multicolumn{4}{|l|}{ Nisoldipine } \\
\hline Ruddy and Fodor, $1997^{42}$ & $10-40$ & 138 & 18.8 \\
\hline \multicolumn{4}{|l|}{ Nitrendipine } \\
\hline Gennari et al, $1989^{44}$ & 10 & 12 & 16.7 \\
\hline Morgan et al, $1990^{45}$ & $20-40$ & 38 & 5.3 \\
\hline \multicolumn{4}{|c|}{ Nondihydropyridine Calcium Channel Blockers } \\
\hline \multicolumn{4}{|l|}{ Diltiazem } \\
\hline Pool et al, $1986^{58}$ & $120-360$ & 45 & 8.9 \\
\hline Weir et al, $1987^{60}$ & $240-360$ & 39 & 2.6 \\
\hline Hedner et al, $1990^{59}$ & $120-360$ & 63 & 4.8 \\
\hline Ruddy et al, $1995^{61}$ & $180-360$ & 54 & 5.6 \\
\hline Ruddy et al, $1995^{61}$ & $180-360$ & 57 & 8.8 \\
\hline Nilsson et al, $1996^{62}$ & $240-420$ & 138 & $2-7$ \\
\hline Cushman et al, $1998^{57}$ & 120 & 150 & 2.7 \\
\hline Cushman et al, $1998^{57}$ & 180 & 152 & 3.3 \\
\hline \multicolumn{4}{|l|}{ Verapamil } \\
\hline Speders, $1989^{51}$ & $240-480$ & 4,247 & 0.7 \\
\hline Gradman et al, $1992^{42}$ & 240 & 72 & 4.2 \\
\hline Karlberg et al, $2000^{52}$ & 240 & 96 & 13.5 \\
\hline White et al, $2001^{50}$ & $180-540$ & 580 & 2.8 \\
\hline \multicolumn{4}{|l|}{$\alpha$-Blockers } \\
\hline Doxazosin & & & \\
\hline Ott et al, $1987^{72}$ & $1-16$ & 63 & 12.7 \\
\hline Prazosin & & & \\
\hline Melkid, $1984^{80}$ & $2-4$ & 79 & 10.1 \\
\hline Goldberg et al, $1988^{24}$ & $2-20$ & 193 & 22.3 \\
\hline Angiotensin-Converting Enzyme In & & & \\
\hline Benazapril & & & \\
\hline Frishman et al, $1995^{31}$ & 10 & 85 & 1.2 \\
\hline Kushnir et al, $1996^{32}$ & 20 & 77 & 1.3 \\
\hline Captopril & & & \\
\hline Gennari et al, $1989^{44}$ & 50 & 12 & 0.0 \\
\hline MacLean, $1994^{88}$ & 50 & 29 & 0.0 \\
\hline
\end{tabular}




\begin{tabular}{|c|c|c|c|}
\hline $\begin{array}{l}\text { Medication } \\
\text { Reference }\end{array}$ & Total Daily Dose (mg) & Sample Size & Edema $(\%)$ \\
\hline \multicolumn{4}{|l|}{ Enalapril } \\
\hline Eisner et al, $1991^{40}$ & $5-40$ & 82 & 0.0 \\
\hline Gradman et al, $1997^{38}$ & $5-20$ & 133 & 3.8 \\
\hline Cushman et al, $1998^{57}$ & 5 & 144 & 3.5 \\
\hline \multicolumn{4}{|l|}{ Lisinopril } \\
\hline Ruddy and Fodor, $1997^{42}$ & $5-20$ & 140 & 2.9 \\
\hline \multicolumn{4}{|l|}{ Ramipril } \\
\hline Schloze et al, $1999^{39}$ & $2.5-10$ & 125 & 0.0 \\
\hline \multicolumn{4}{|l|}{ Trandolapril } \\
\hline Steiner and Pauly, $1994^{27}$ & 2 & 54 & 7.4 \\
\hline Karlberg et al, $2000^{52}$ & 2 & 96 & 4.2 \\
\hline \multicolumn{4}{|l|}{ Captopril, Enalapril, or } \\
\hline \multicolumn{4}{|l|}{ Lisinopril } \\
\hline Goldberg et al, $1995^{24}$ & Unspecified & 239 & 1.7 \\
\hline \multicolumn{4}{|l|}{ Enalapril or Lisinopril } \\
\hline Hansson et al, $1999^{11}$ & 10 & 2,205 & 8.7 \\
\hline \multicolumn{4}{|l|}{ Angiotensin Receptor Blockers } \\
\hline \multicolumn{4}{|l|}{ Candesartan } \\
\hline Kloner et al, $2001^{34}$ & $16-32$ & 123 & 8.9 \\
\hline \multicolumn{4}{|l|}{ Irbesartan } \\
\hline Oparil et al, $2001^{103}$ & 150 & 145 & 0.7 \\
\hline \multicolumn{4}{|l|}{ Losartan } \\
\hline Goldberg et al, $1995^{24}$ & Unspecified & 2,085 & 1.7 \\
\hline Oparil et al, 2001 & 50 & 146 & 0.0 \\
\hline Dahlof et al, $2002^{105}$ & $50-100$ & 4,605 & 11.7 \\
\hline \multicolumn{4}{|l|}{ Olmesartan } \\
\hline Neutel, $2001^{102}$ & $2.5-80$ & 2,540 & 0.8 \\
\hline Oparil et al, $2001^{103}$ & 20 & 145 & 0.7 \\
\hline \multicolumn{4}{|l|}{ Valsartan } \\
\hline Corea et al, $1996^{33}$ & 80 & 84 & 2.4 \\
\hline Oparil et al, $2001^{103}$ & 80 & 142 & 2.1 \\
\hline Biswas et al, $2002^{104}$ & Unspecified & 12,881 & 1.4 \\
\hline \multicolumn{4}{|l|}{$\beta$-Blockers } \\
\hline \multicolumn{4}{|l|}{ Atenolol } \\
\hline Daniels and Opie, $1986^{23}$ & 100 & 35 & 5.7 \\
\hline Ott et al, $1987^{72}$ & $50-100$ & 63 & 6.3 \\
\hline Weir et al, $1987^{60}$ & $50-100$ & 39 & 2.6 \\
\hline Heagerty et al, $1988^{25}$ & $50-100$ & 200 & 1.0 \\
\hline UK Lacdipine, $1991^{43}$ & 50 & 265 & 3.8 \\
\hline Goldberg et al, $1995^{24}$ & Unspecified & 68 & 1.5 \\
\hline Dahlof et al, $2002^{105}$ & $50-100$ & 4,588 & 13.9 \\
\hline \multicolumn{4}{|l|}{ Carvedilol } \\
\hline Morgan et al, $1990^{45}$ & $12.5-50$ & 103 & 0.0 \\
\hline \multicolumn{4}{|l|}{ Dilavelol } \\
\hline Materson et al, $1989^{112}$ & $200-1600$ & 310 & 1.0 \\
\hline \multicolumn{4}{|l|}{ Metoprolol } \\
\hline Freeling et al, $1987^{35}$ & 100 & 32 & 0.0 \\
\hline Materson et al, $1989^{112}$ & $100-400$ & 137 & 2.9 \\
\hline Hedner et al, $1990^{59}$ & $50-200$ & 63 & 4.8 \\
\hline Feliciano et al, $1990^{113}$ & $100-400$ & 126 & 3.2 \\
\hline Dahlof and Hosie, $1990^{36}$ & 100 & 52 & 0.0 \\
\hline Pindolol & & & \\
\hline Morgan et al, $1990^{45}$ & Unspecified & 39 & 0.0 \\
\hline Diuretics & & & \\
\hline HCTZ & & & \\
\hline Goldberg et al, $1995^{24}$ & Unspecified & 27 & 1.8 \\
\hline HCTZ plus amiloride & & & \\
\hline Brown et al, $2000^{28}$ & $25-50 / 2.5-5$ & 3,164 & 4.3 \\
\hline
\end{tabular}

a group treated with felodipine, and $2 \%$ to $20 \%$ in the placebo groups. ${ }^{23,24}$ In non-placebo-controlled studies, the rates of edema with dihydropyridine CCBs ranged from $5 \%$ to $28 \%$ with nifedipine, ${ }^{25-29} 2 \%$ to $32 \%$ with amlodipine, ${ }^{29-34} 0 \%$ to $30 \%$ with felodipine, ${ }^{24,26,30,35-39} 8 \%$ to $14 \%$ with isradipine, ${ }^{37,40} 8 \%$ to $15 \%$ with nicardipine, ${ }^{41} 19 \%$ with nisoldipine, ${ }^{42} 6 \%$ with lacdipine, ${ }^{43}$ and $5 \%$ to $17 \%$ with nitrendipine. ${ }^{44,45}$ Two non-placebocontrolled studies, one using nifedipine and the other isradipine, did not report edema as an adverse event. ${ }^{46,47}$

The nondihydropyridine CCBs verapamil and diltiazem also promote leg and ankle swelling. ${ }^{48}$ 
Verapamil increases plasma volume, ${ }^{15}$ and it blunts postural cutaneous vasoconstriction in the lower extremities, as do amlodipine and nifedipine. ${ }^{49}$ One placebo controlled study found that the prevalence of edema in patients with hypertension who were treated with verapamil was $3 \%$ compared with $5 \%$ in the placebo group. ${ }^{50}$ Other non-placebo-controlled studies have found a $1 \%$ to $14 \%$ frequency of edema in subjects treated with verapamil. ${ }^{41,51,52}$ Several uncontrolled studies did not report edema as an adverse event of verapamil. ${ }^{53-56}$

The frequency of edema in subjects treated with diltiazem is less variable than with verapamil. In placebo-controlled studies, the frequency of edema in the diltiazem group varied from $2 \%$ to $9 \%$, compared with 0 to $3.3 \%$ in the placebo group. ${ }^{57-59}$ Non-placebo-controlled studies have found the frequency of edema with diltiazem to be $2 \%$ to $9 \% .{ }^{60-62}$ Two non-placebo-controlled studies did not report edema as an adverse event of diltiazem. $^{46,63}$

\section{$\alpha$-Blockers}

$\alpha$-blockers promote fluid retention. ${ }^{64,65}$ Prazosin increases plasma volume, extracellular fluid volume, and weight. ${ }^{66-71}$ Doxazosin promotes weight gain in many, but not all, patients. ${ }^{71-74}$ Terazosin also causes weight gain, ${ }^{75-78}$ whereas withdrawing terazosin results in weight loss. ${ }^{79}$

In a placebo-controlled study, edema was present in $22 \%$ of subjects treated with prazosin compared with $3 \%$ of the subjects in the placebo group. ${ }^{70}$ In studies lacking a placebo group, edema occurred in $10 \%$ of subjects treated with prazosin ${ }^{80}$ and in $13 \%$ of subjects using doxazosin. ${ }^{72}$

\section{Angiotensin-Converting Enzyme Inhibitors}

ACEIs do not promote fluid retention. ${ }^{81}$ Captopril has natriuretic effects, reduces body weight, and lessens extracellular fluid volume. ${ }^{82-84}$ Enalapril has been shown to cause transient increases in interstitial fluid volume after 1 week of administration, but these increases are short-lived, and extracellular fluid volume returns to baseline after 6 weeks of therapy. ${ }^{85}$ Other studies have demonstrated that changes in body weight, extracellular fluid, and plasma volume are minimal with ACEIs. ${ }^{86,87}$

Most studies have reported a low prevalence of edema in subjects treated with an ACEI. The rates of edema have varied from $0 \%$ with captopril, ${ }^{44,88}$ $0 \%$ to $4 \%$ with enalapril, ${ }^{38,40,57} 3 \%$ with lisinopril, $^{42} 1 \%$ with benazapril, ${ }^{31,32} 0 \%$ with ramipril, ${ }^{39}$ $4 \%$ to $7 \%$ with trandolapril, ${ }^{27,52} 2 \%$ in a study that used captopril, enalapril, or lisinopril, ${ }^{24}$ and $9 \%$ in a study that used enalapril or lisinopril. ${ }^{11}$ Only 4 of these studies were placebo-controlled, but in all 4, the frequency of edema in the ACEI group was comparable with or lower than the frequency of edema in the placebo group. ${ }^{24,31,32,57}$ Finally, a number of uncontrolled studies using ACEIs did not report edema as an adverse event. ${ }^{44,54,56,89-95}$

Adding an ACEI to a dihydropyridine CCB lessens the edema caused by the CCB. ${ }^{27,31,32,38,39,92,96-98}$ The ability to dilate the venous capacitance vessels, thereby reducing elevated intracapillary and venous pressures brought about by the arteriole dilation of the $\mathrm{CCB}$, is the likely mechanism by which ACEIs reduce the leg edema associated with CCBs. ${ }^{96,99}$ ACEIs also reduce edema caused by diabetic nephropathy. ${ }^{100}$

\section{Angiotensin Receptor Blockers}

Like ACEIs, ARBs reduce edema. Valsartan promotes natriuresis and diuresis. ${ }^{101}$ In placebo controlled studies, losartan had a $1.7 \%$ edema rate compared with a $1.9 \%$ rate in the placebo group, ${ }^{24}$ and olmesartan had a $0.8 \%$ edema rate compared with a $1.1 \%$ rate in the placebo group. ${ }^{102}$ Nonplacebo-controlled studies using ARBs have reported variable rates of edema: $0.7 \%$ with olmesartan, ${ }^{103} 1.4$ to $2.4 \%$ with valsartan, ${ }^{33,103,104} 0.7 \%$ with irbesartan, ${ }^{103} 9 \%$ with candesartan, ${ }^{34}$ and $12 \%$ with losartan. ${ }^{105}$ In the losartan trial, many of the subjects were also treated with HCTZ, thereby raising the question as to whether the edema rate would have been higher were it not for the use of the diuretic. ${ }^{105}$ Two uncontrolled studies involving losartan and telmisartan did not report edema as an adverse event. ${ }^{56,106}$

\section{及-Blockers}

Edema formation and fluid retention are not considered side effects of $\beta$-blockers. ${ }^{107-110}$ Two studies have reported either an absence of weight gain, or nonsignificant weight gain, in subjects treated with atenolol. ${ }^{73,84}$ In placebo controlled studies of atenolol, metoprolol CR, and pindolol, the edema rates for the $\beta$-blockers varied from $1.7 \%$ to $6 \%$ 
compared with $1.9 \%$ to $20 \%$ in the placebo groups. $^{23,24,59,111}$

A number of non-placebo-controlled studies of $\beta$-blockers have reported variable rates of edema: $1 \%$ to $6 \%$ for atenolol $2^{25,43,60,72} ; 0 \%$ to $5 \%$ for metoprolol $^{35,36,59,112,113} ; 0 \%$ for carvedilol ${ }^{45} ; 0 \%$ for pindolol ${ }^{45}$; and $1 \%$ for dilevalol. ${ }^{112}$

Two trials that lacked a placebo group documented lower extremity edema frequently in subjects treated with $\beta$-blockers. The LIFE trial found that $14 \%$ of subjects in the atenolol arm of the trial had edema, ${ }^{105}$ and the STOP-Hypertension-2 study found an edema rate of $8.5 \%$ in the group treated with atenolol, metoprolol, pindolol, or HCTZ plus amiloride. ${ }^{11}$ Because some of the subjects treated with $\beta$-blockers in both the LIFE trial and the STOP-Hypertension-2 study were also treated with a diuretic, the rate of edema associated with $\beta$-blockers might have been even higher were it not for the diuretic. Finally, numerous nonplacebo-controlled studies of metoprolol, atenolol, propranolol, and pindolol did not report edema as an adverse event.*

\section{Diuretics}

Only 2 studies have reported the frequency of edema in subjects treated with thiazide diuretics. A placebo controlled study found the edema rate in subjects treated with HCTZ to be $1.8 \%$, whereas the edema rate in the placebo group was $1.9 \% .{ }^{24} \mathrm{~A}$ non-placebo-controlled study found a $4.3 \%$ edema rate in the group treated with a 2-diuretic regimen consisting of HCTZ plus amiloride. ${ }^{28}$ It is surprising that so many patients with hypertension who were treated with a diuretic had any edema whatsoever. One possible explanation is that many of these subjects may have had edema before enrolling in the study. HCTZ decreases the leg edema associated with CCBs, although not as effectively as ACEIs. ${ }^{98}$

\section{Limitations}

There are limitations involved in comparing fluid retention properties between different trials of antihypertensive medications. The most important limitation is using weight change or leg edema as proxy markers for total body fluid. It is significant that many cardiovascular experts consider leg

${ }^{*}$ Refs. 53, 89, 90, 93, 94, 106, 110, and 114-116. edema caused by CCBs to be a local phenomenon that should not be considered fluid retention. In response to this argument, one can only provide a common sense answer: fluid is fluid. The leg edema resulting from CCBs looks and feels the same as the leg edema that results from heart failure. CCBs promote natriuresis and diuresis, but this does not eliminate the possibility of a simultaneous increase in total body fluid. Experts who claim that the leg edema associated with CCBs does not represent fluid retention focus on the role of the kidneys but ignore the gastrointestinal tract. They forget that intake of salt and water is not static. In response to the increased natriuresis and diuresis of CCBs, humans can compensate by increasing their ingestion and absorption of salt and water. As a result, the amount of intravascular fluid can remain constant with CCBs, or perhaps even increase because of vasodilation, whereas interstitial fluid in the form of leg edema increases. Therefore, total body fluid can increase simultaneously with increased renal excretion of salt and water.

A second limitation is that adverse events typically increase with higher dosages of medication. Although it may be fair to contrast the frequency and severity of leg edema between different antihypertensive medications by comparing starting doses and maximal doses, many antihypertensive trials use a range of doses of the same medication in the same study, thereby raising difficulties in comparing the frequency of adverse events between trials.

Another limitation is that adverse events may increase with prolonged medication usage. Some antihypertensive trials last for months and others last for years. As a result, it is reasonable to question whether the frequency and severity of adverse events identified in a trial of short duration are comparable with the frequency and severity of adverse events identified in a trial of long duration.

In addition, the majority of antihypertensive trials do not include a placebo group. For these studies, it is not clear whether the adverse events that occur are attributable to the medication or to other factors. Many antihypertensive trials use 2 medications, and each medication serves as a control for the other, but this is not the same as using a placebo control.

Many trials of antihypertensive medications allow the usage of multiple medications if blood pressure is inadequately controlled after adminis- 
tration of the initial medication. These additional medications have their own properties and side effects, thereby confounding any attempt to determine the adverse events attributable to the initial medication.

Finally, although many antihypertensive trials report the prevalence of adverse events, including edema, after the administration of the study medication, none mention the prevalence of these conditions before initiating therapy. The prevalence of idiopathic edema has not been documented in subjects with hypertension, but idiopathic edema and hypertension are both associated with obesity. ${ }^{117}$ Therefore, there may be a relationship between idiopathic edema and hypertension, and edema that is reported as an adverse event in antihypertensive trials may have been present before subjects enrolled in the study. It is a deficiency of the entire antihypertensive literature that investigators do not include information as to the edema rate of enrollees before the study. Future antihypertensive trials can correct this inadequacy by reporting the prevalence of edema as a baseline characteristic of participants.

\section{Conclusion}

In summary, the fluid reduction property of diuretics, ACEIs, and ARBs, the fluid neutral property of $\beta$-blockers, and the fluid retention property of CCBs and $\alpha$-blockers provide a theoretical basis by which to rank the different classes of antihypertensive medications in a hierarchical manner. Diuretics are the preferred agents for treating hypertension, followed closely by ACEIs and ARBs. $\beta$-Blockers are next in terms of preference, and CCBs and $\alpha$-blockers are the least preferred medications for treating hypertension.

I thank Drs. Robert Bahler, Michael Deucher, and Kurt Stange for reviewing and improving the manuscript.

\section{References}

1. Pahor M, Psaty BM, Alderman MH, Applegate WB, Williamson JD, Cavazzini C, Furberg CD. Health outcomes associated with calcium antagonists compared with other first-line antihypertensive therapies: a meta-analysis of randomised controlled trials. Lancet 20009;356:1949-54.

2. Neal B, MacMahon S, Chapman N; Blood Pressure Lowering Treatment Trialists' Collaboration. Effects of ACE inhibitors, calcium antagonists, and other blood-pressure-lowering drugs: results of prospectively designed overviews of randomised trials. Blood Pressure Lowering Treatment Trialists' Collaboration. Lancet 2000;356:1955-64.

3. ALLHAT Collaborative Research Group. Major cardiovascular events in hypertensive patients randomized to doxazosin vs chlorthalidone: the antihypertensive and lipid-lowering treatment to prevent heart attack trial (ALLHAT). JAMA 2000;283: 1967-75. Erratum in: JAMA 2002;288:2976.

4. ALLHAT Officers and Coordinators for the ALLHAT Collaborative Research Group. The Antihypertensive and Lipid-Lowering Treatment to Prevent Heart Attack Trial. Major outcomes in high-risk hypertensive patients randomized to angiotensin-converting enzyme inhibitor or calcium channel blocker vs diuretic: The Antihypertensive and Lipid-Lowering Treatment to Prevent Heart Attack Trial (ALLHAT). JAMA 2002;288:2981-97. Erratum in: JAMA 2003;289:178 and JAMA 2004; 291:2196.

5. Psaty BM, Lumley T, Furberg CD, et al. Health outcomes associated with various antihypertensive therapies used as first-line agents: a network metaanalysis. JAMA 2003;289:2534-44.

6. Chobanian AV, Bakris GL, Black HR, et al; National Heart, Lung, and Blood Institute Joint National Committee on Prevention, Detection, Evaluation, and Treatment of High Blood Pressure; National High Blood Pressure Education Program Coordinating Committee. The Seventh Report of the Joint National Committee on Prevention, Detection, Evaluation, and Treatment of High Blood Pressure: the JNC 7 report. JAMA 2003;289:2560-72. Erratum in: JAMA 2003; 290:197.

7. Wing LM, Reid CM, Ryan P, et al; Second Australian National Blood Pressure Study Group. A comparison of outcomes with angiotensin-converting-enzyme inhibitors and diuretics for hypertension in the elderly. N Engl J Med 2003;348:583-92.

8. Hansson L, Hedner T, Lund-Johansen P, et al. Randomised trial of effects of calcium antagonists compared with diuretics and beta-blockers on cardiovascular morbidity and mortality in hypertension: the Nordic Diltiazem (NORDIL) study. Lancet 2000;356:359-65.

9. Zanchetti A, Rosei EA, Dal Palu C, Leonetti G, Magnani B, Pessina A. The Verapamil in Hypertension and Atherosclerosis Study (VHAS): results of long-term randomized treatment with either verapamil or chlorthalidone on carotid intima-media thickness. J Hypertens 1998;16:1667-76.

10. Black HR, Elliott WJ, Grandits G, Grambsch P, et al; CONVINCE Research Group. Principal results of the Controlled Onset Verapamil Investigation of Cardiovascular End Points (CONVINCE) trial. JAMA 2003;289:2073-82.

11. Hansson L, Lindholm LH, Ekbom T, et al. Ran- 
domised trial of old and new antihypertensive drugs in elderly patients: cardiovascular mortality and morbidity the Swedish Trial in Old Patients with Hypertension-2 study. Lancet 1999;354:1751-6.

12. Hansson L, Lindholm LH, Niskanen L, et al. Effect of angiotensin-converting-enzyme inhibition compared with conventional therapy on cardiovascular morbidity and mortality in hypertension: the Captopril Prevention Project (CAPPP) randomised trial. Lancet 1999;353:611-6.

13. Olsson G, Tuomilehto J, Berglund G, et al. Primary prevention of sudden cardiovascular death in hypertensive patients: mortality results from the MAPHY study. Am J Hypertens 1991;4:151-8.

14. Weber M. The ALLHAT report: a case of information and misinformation. J Clin Hypertens 2003; $5: 9-13$.

15. de Leeuw PW, Birkenhäger WH. Effects of verapamil in hypertensive patients. Acta Med Scand 1984;681 Suppl:125-8.

16. Conlin PR, Williams GH. Use of calcium channel blockers in hypertension. Adv Intern Med 1998;43: $533-62$.

17. van Hamersvelt HW, Kloke HJ, de Jong DJ, Koene RAP, Huysmans TM. Oedema formation with the vasodilators nifedipine and diazoxide: direct local effect or sodium retention? J Hypertens 1996;14: $1041-5$.

18. Loutzenhiser R, Epstein M. Effects of calcium antagonists on renal hemodynamics. Am J Physiol 1985;249:F619-29.

19. Kaplan NM. Calcium entry blockers in the treatment of hypertension: current status and future prospects. JAMA 1989;262:817-23.

20. Epstein M, De Micheli AG. Natriuretic effects of calcium antagonists. In: Calcium antagonists in clinical medicine. Epstein M, editor. Philadelphia: Hanley and Belfus; 1992. p. 349-66.

21. Ene MD, Williamson PJ, Roberts CJC, Waddell G. The natriuresis following oral administration of the calcium antagonists-nifedipine and nitrendipine. Br J Clin Pharmacol 1985;19:423-7.

22. Ciccone M, Di Noia D, Di Michele L, Corriero F, Biasco, Rizzon P. Effects of lacidipine and nifedipine on the lower limb veins of nonphlebopathic patients. J Cardiovasc Pharmacol 1994;23:S111-2.

23. Daniels AR, Opie LH. Atenolol plus nifedipine for mild to moderate systemic hypertension after fixed doses of either agent alone. Am J Cardiol 1986;57: 965-70.

24. Goldberg AI, Dunlay MC, Sweet CS. Safety and tolerability of losartan potassium, an angiotensin II receptor antagonist, compared with hydrochlorothiazide, atenolol, felodipine ER, and angiotensin-converting enzyme inhibitors for the treatment of systemic hypertension. Am J Cardiol 1995;75: 793-5.

25. Nifedipine and atenolol singly and combined for treatment of essential hypertension: comparative multicentre study in general practice in the United Kingdom. Nifedipine-Atenolol Study Review Committee. Br Med J (Clin Res Ed) 1988;296: $468-72$.

26. Fagan TC, Haggert BE, Liss C. Efficacy and tolerability of extended felodipine and extended-release nifedipine in patients with mild-to-moderate hypertension. Clin Ther 1994;16:634-46.

27. Steiner G, Pauly NC. Comparison of the efficacy and safety of trandolapril and nifedipine SR in mild-to-moderate hypertension. J Cardiovasc Pharmacol 1994;4:S81-5.

28. Brown MJ, Palmer CR, Castaigne A, et al. Morbidity and mortality in patients randomised to doubleblind treatment with a long-acting calcium-channel blocker or diuretic in the International Nifedipine GITS study: Intervention as a Goal in Hypertension Treatment (INSIGHT). Lancet 2000;356: 366-72. Erratum in: Lancet 2000;356:514.

29. Messerli FH, Oparil S, Feng Z. Comparison of efficacy and side effects of low-dose combination therapy of angiotensin-converting enzyme inhibitor (benazepril) with calcium antagonist (either nifedipine or amlodipine) versus high dose calcium antagonist monotherapy for systemic hypertension. Am J Cardiol 2000;86:1182-7.

30. Koenig W. Efficacy and tolerability of felodipine and amlodipine in the treatment of mild to moderate hypertension: a randomized double blind multicentre trial. Drug Investig 1993;5:200-5.

31. Frishman WH, Ram CV, McMahon FG, et al. Comparison of amlodipine and benazepril monotherapy to amlodipine plus benazepril in patients with systemic hypertension: a randomized, doubleblind, placebo-controlled, parallel-group study. The Benazepril/Amlodipine Study Group. J Clin Pharmacol 1995;35:1060-6.

32. Kuschnir E, Acuna E, Sevilla D, et al. Treatment of patients with essential hypertension: amlodipine 5 $\mathrm{mg} /$ benazepril $20 \mathrm{mg}$ compared with amlodipine 5 $\mathrm{mg}$, benazepril $20 \mathrm{mg}$, and placebo. Clin Ther 1996;18:1213-24.

33. Corea L, Cardoni O, Fogari R, et al. Valsartan, a new angiotensin II antagonist for the treatment of essential hypertension: a comparative study of the efficacy and safety against amlodipine. Clin Pharmacol Ther 1996;60:341-6.

34. Kloner RA, Weinberger M, Pool JL, et al; Comparison of Candesartan and Amlodipine for Safety, Tolerability and Efficacy (CASTLE) Study Investigators. Comparative effects of candesartan cilexetil and amlodipine in patients with mild systemic hypertension. Comparison of Candesartan and Amlodipine for Safety, Tolerability and Efficacy (CASTLE) Study Investigators. Am J Cardiol 2001;87:727-31.

35. Freeling P, Davis RH, Goves JR, Burton RH, 
Orme-Smith EA. Control of hypertension in elderly patients with felodipine and metoprolol: a double-blind, placebo controlled clinical trial. $\mathrm{Br} \mathrm{J}$ Clin Pharmacol 1987;24:459-64.

36. Dahlöf B, Hosie J. Antihypertensive efficacy and tolerability of a fixed combination of metoprolol and felodipine in comparison with the individual substances in monotherapy. J Cardiovasc Pharmacol 1990;16:910-6.

37. Hammond JJ, Cutler SA. A comparison of isradipine and felodipine in Australian patients with hypertension: focus on ankle oedema. The Physician's Study Group. Blood Press 1993;2:205-11.

38. Gradman AH, Cutler NR, Davis PJ, Robbins JA, Weiss RJ, Wood BC. Combined enalapril and felodipine extended release (ER) for systemic hypertension: Enalapril-Felodipine ER Factorial Study Group. Am J Cardiol 1997;79:431-5.

39. Scholze J, Bauer B, Massaro J. Antihypertensive profiles with ascending dose combinations of ramipril and felodipine ER. Clin Exp Hypertens 1999;21:1447-62.

40. Eisner GM, Johnson BF, McMahon FG, et al. A multicenter comparison of the safety and efficacy of isradipine and enalapril in the treatment of hypertension. Am J Hypertens 1991;4:154S-157S.

41. Gradman AH, Frishman WH, Kaihlanen PM, Wong SC, Friday KJ. Comparison of sustainedrelease formulations of nicardipine and verapamil for mild to moderate systemic hypertension. Am J Cardiol 1992;70:1571-5.

42. Ruddy TD, Fodor JG. Nisoldipine CC and lisinopril alone or in combination for treatment of mild to moderate systemic hypertension. Cardiovasc Drugs Ther 1997;11:581-90.

43. United Kingdom Lacidipine Study Group. A double-blind comparison of the efficacy and safety of lacidipine with atenolol in the treatment of essential hypertension. J Cardiovasc Pharmacol 1991; 17:S27-30.

44. Gennari C, Renato N, Pavese G, Gragnani S, Bianchini C, Buracchi P. Calcium-channel blockade (nitrendipine) in combination with ACE inhibition (captopril) in the treatment of mild to moderate hypertension. Cardiovasc Drugs Ther 1989;3:31925.

45. Morgan TO, Anderson A, Cripps J, Adam W. The use of carvedilol in elderly hypertensive patients. Eur J Clin Pharmacol 1990;38:S129-33.

46. Hosie J, Nasar MA, Belgrave GP, Walters EG. A comparative study of long acting diltiazem (tildiem LA) with sustained release nifedipine (nifedipine SR0 and bendrofluazide in the treatment of mild to moderate hypertension. Acta Cardiol 1994;49:25165.

47. Borhani NO, Mercuri M, Borhani PA, et al. Final outcome results of the multicenter isradipine di- uretic atherosclerosis study (MIDAS): a randomized controlled trial. JAMA 1996;276:785-91.

48. Pedrenelli R, Dell'Omo G, Mariani M. Calcium channel blockers, postural vasoconstriction and dependent oedema in essential hypertension. J Hum Hypertens 2001;15:455-61.

49. Iabichella ML, Dell'Omo G, Melillo E, Pedrinelli R. Calcium channel blockers blunt postural cutaneous vasoconstriction in hypertensive patients. Hypertension 1997;29:751-6.

50. White WB, Johnson MF, Anders RJ, Elliott WJ, Black HR. Safety of controlled-onset extendedrelease verapamil in middle-aged and older patients with hypertension and coronary artery disease. Am Heart J 2001;142:1010-5.

51. Speders S, Sosna J, Schumacher A, Pfennigsdorf G. Efficacy and safety of verapamil SR $240 \mathrm{mg}$ in essential hypertension: results of a multicentric phase IV study. J Cardiovasc Pharmacol 1989;13: S47-9.

52. Karlberg BE, Andrup M, Odén A, et al. Efficacy and safety of a new long-acting drug combination, trandolapril/verapamil as compared to monotherapy in primary hypertension. Swedish TARKA trialists. Swedish Tarka trialists. Blood Press 2000; 9:140-5.

53. Cubeddu LX, Aranda J, Singh B. A comparison of verapamil and propranolol for the initial treatment of hypertension: racial differences in response. JAMA 1986;256:2214-21.

54. Levine JH, Ferdinand KC, Cargo P, Laine H, Lefkowitz $M$. Additive effects of verapamil and enalapril in the treatment of mild to moderate hypertension. Am J Hypertens 1995;8:494-9.

55. Rosei EA, Dal Palù C, Leonetti G, Magnani B, Pessina A, Zanchetti A. Clinical results of the Verapamil in Hypertension and Atherosclerosis Study. VHAS Investigators. J Hypertens 1997;15:133744.

56. Bakris G, Sica D, Ram V, Fagan T, Vaitkus PT, Anders RJ. A comparative trial of controlled-onset, extended-release verapamil, enalapril, and losartan on blood pressure and heart rate changes. Am J Hypertens 2002;15:53-7.

57. Cushman WC, Cohen JD, Jones RP, Marbury TC, Rhoades RB, Smith LK. Comparison of the fixed combination of enalapril/diltiazem ER and their monotherapies in stage 1 to 3 essential hypertension. Am J Hypertens 1998;11:23-30.

58. Pool PE, Massie BM, Venkataraman K, et al. Diltiazem as monotherapy for systemic hypertension: a multicenter, randomized, placebo-controlled trial. Am J Cardiol 1986;57:212-7.

59. Hedner T, Thulin T, Gustafsson S, Olsson SO. A comparison of diltiazem and metoprolol in hypertension. Swedish Diltiazem-Metoprolol Multicentre Study Group. Eur J Clin Pharmacol 1990;39: 427-33. 
60. Weir MR, Josselson J, Giard MJ, et al. Sustainedrelease diltiazem compared with atenolol monotherapy for mild to moderate systemic hypertension. Am J Cardiol 1987;60:36I-41I.

61. Ruddy TD, Wright JM, Savard D, Handa SP, Chockalingam A, Boulet AP. Comparison of the efficacy and safety of once-daily versus twice-daily formulations of diltiazem in the treatment of systemic hypertension. Cardiovasc Drugs Ther 1995; 9:413-20.

62. Nilsson P, Lindholm LH, Hedner T. The diltiazem different doses study-a dose-response study of once-daily diltiazem therapy for hypertension. J Cardiovasc Pharmacol 1996;27:469-75.

63. Woehler TR, Eff J, Graney W, Heald D, Ziemniak J, Magner D. Multicenter evaluation of the efficacy and safety of sustained-release diltiazem hydrochloride for the treatment of hypertension. Clin Ther 1992;14:148-57.

64. Warren JB, Dollery CT. The usefulness of alphaadrenoceptor blockade in the treatment of hypertension. J Hypertens 1988;6:S43-9.

65. Bryson CL, Psaty BM. A review of the adverse effects of peripheral alpha-1 antagonists in hypertension therapy. Curr Control Trials Cardiovasc Med 2002;3:7.

66. Koshy MC, Mickley D, Bourgiognie J, Blaufox MD. Physiological evaluation of a new antihypertensive agent: prazosin $\mathrm{HCl}$. Circulation 1977;55: 533-7.

67. McNair A, Rasmussen S, Nielsen PE, Rasmussen $\mathrm{K}$. The antihypertensive effect of prazosin on mild to moderate hypertension, changes in plasma volume, extracellular volume and glomerular filtration rate. Acta Med Scand 1980;207:413-6.

68. Bauer JH, Jones LB, Gaddy P. Effects of prazosin therapy on BP, renal function, and body fluid composition. Arch Intern Med 1984;144:1196-200.

69. Riegger GA, Haeske W, Kraus C, Kromer EP, Kochsiek K. Contribution of the renin-angiotensin system to development of tolerance and fluid retention in chronic congestive heart failure during prazosin treatment. Am J Cardiol 1987;59:906-10.

70. Goldberg MR, Sushak CS, Rockfold FW, Thompson WL. Vasodilator monotherapy in the treatment of hypertension: comparative efficacy and safety of pinacidil, a potassium channel opener, and prazosin. Clin Pharmacol Ther 1988;44:78-92.

71. Torvik D, Madsbu H-P. Multicentre 12-week double-blind comparison of doxazosin, prazosin and placebo in patients with mild to moderate essential hypertension. Br J Clin Pharmacol 1986;21: S69-75.

72. Ott P, Storm TL, Krusell LR, Jensen H, Badskjaer J, Faergeman O. Multicenter, double-blind comparison of doxazosin and atenolol in patients with mild to moderate hypertension. Am J Cardiol 1987; 59:73G-77G.
73. Carruthers G, Dessain P, Fodor G, Newman C, Palmer W, Sim D. Comparative trial of doxazosin and atenolol on cardiovascular risk reduction in systemic hypertension. The Alpha Beta Canada Trial Group. Am J Cardiol 1993;71:575-81.

74. Krusell LR, Christensen CK, Pedersen OL. Alphaadrenoreceptor blockade in patients with mild to moderate hypertension: long-term renal effects of doxazosin. J Cardiovasc Pharmacol 1992;20:440-4.

75. Deger G. Comparison of the safety and efficacy of once-daily terazosin versus twice-daily prazosin for the treatment of mild to moderate hypertension. Am J Med 1986;80:62-7.

76. Mersey JH. Long-term experience with terazosin for treatment of mild to moderate hypertension. Am J Med 1986;80:68-72.

77. Sperzel WD, Glassman HN, Jordan DC, Luther RR. Overall safety of terazosin as an antihypertensive agent. Am J Med 1986;80:77-81.

78. Luther RR, Glassman HN, Estep CB, Schmitz PJ, Horton JK, Jordan DC. Terazosin, a new selective alpha 1-adrenergic blocking agent: results of longterm treatment in patients with essential hypertension. Am J Hypertens 1988;1:237S-240S.

79. Ruoff G. Effect of withdrawal of terazosin therapy in patients with hypertension. Am J Med 1986;80: 35-41.

80. Melkid A. Prazosin ('Peripress'): a long-term study. Curr Med Res Opin 1984;9:219-28.

81. Williams GH. Converting-enzyme inhibitors in the treatment of hypertension. N Engl J Med 1988;319: $1517-25$.

82. Atlas SA, Case DB, Sealey JE, Laragh JH, McKinstry DN. Interruption of the renin-angiotensin system in hypertensive patients by captopril induces sustained reduction in aldosterone secretion, potassium retention and natriuresis. Hypertens $1979 ; 1: 274-80$.

83. de Bruyn JHB, Man in't Veld AJ, Wenting GJ, Derkx FH, Schalekamp MA. Haemodynamic profile of captopril treatment in various forms of hypertension. Eur J Clin Pharmacol 1981;20:163-8.

84. Andrén L, Karlberg BE, Svensson A, Öhman P, Nilsson OR, Hansson L. Long-term effects of captopril and atenolol in essential hypertension. Acta Med Scand 1985;217:155-60.

85. Semplicini A, Rossi GP, Bongiovi S, et al. Time course of changes in blood pressure, aldosterone and body fluids during enalapril treatment: a double-blind randomized study vs hydrochlorothiazide plus propranolol in essential hypertension. Clin Exp Pharmacol Physiol 1986;13:17-24.

86. Tarazi RC, Bravo EL, Fouad RM, Omvik P, Cody RJ. Hemodynamic and volume changes associated with captopril. Hypertension 1980;2:576-85.

87. Wenting GJ, DeBruyn JHB, Man in’T Veld AJ, et al. Hemodynamic effects of captopril in essential 
hypertension, renovascular hypertension and cardiac failure: correlations with short- and long-term effects on plasma renin. Am J Cardiol 1982;49: 1453-9.

88. McLean D. Combination therapy with amlodipine and captopril for resistant systemic hypertension. Am J Cardiol 1994;73:55A-58A.

89. Helgeland A, Strømmen R, Hagelund CH, Tretli S. Enalapril, atenolol and hydrochlorazide in mild to moderate hypertension: a comparative multicentre study in general practice in Norway. Lancet 1986;1:872-5.

90. Comparison of monotherapy with enalapril and atenolol in mild to moderate hypertension. The Canadian Enalapril Study Group. CMAJ 1987;137: 803-8.

91. Rush JE, Lyle PA. Safety and tolerability of lisinopril in older hypertensive patients. Am J Med 1988; 85:S55-9.

92. Pittrow DB, Antlsperger A, Welzel D, Wambach G, Schardt W, Weidenger G. Evaluation of the efficacy and tolerability of a low-dose combination of isradipine and spirapril in the first-line treatment of mild to moderate essential hypertension. Cardiovasc Drugs Ther 1997;11:619-27.

93. Rosenthal J, Bahrmann H, Benkert K, et al. Analysis of adverse effects among patients with essential hypertension receiving an ACE inhibitor or a betablocker. Cardiology 1996;87:409-14.

94. Sierakowski B, Püchler K, Witte PU, Renneisen K, Delius $W$. Comparison of temocapril and atenolol in the long-term treatment of mild to moderate essential hypertension. Blood Press 1997;6:229-34.

95. Bauer B, Lorenz H, Zahlten R. An open multicenter study to assess the long-term efficacy, tolerance, and safety of the oral angiotensin converting enzyme inhibitor ramipril in patients with mild to moderate essential hypertension. J Cardiovasc Pharmacol 1989;13:S70-4.

96. Pedrenelli R, Dell'Omo G, Melillo E, Mariani M. Amlodipine, enalapril, and dependent leg edema in essential hypertension. Hypertens 2000;35:621-5.

97. Guazzi MD, De Cesare N, Galli C, et al. Calciumchannel blockade with nifedipine and angiotensin converting enzyme inhibition with captopril in the therapy of patients with severe primary hypertension. Circulation 1984;70:279-84.

98. Weir MR, Rosenberger C, Fink JC. Pilot study to evaluate a water displacement technique to compare effects of diuretics and ACE inhibitors to alleviate lower extremity edema due to dihydropyridine calcium antagonists. Am J Hypertens 2001;14: 963-8.

99. Zusman RM. Effects of converting enzyme inhibitors on the renin-angiotensin aldosterone, bradykinin, and arachidonic acid-prostaglandin systems: correlation of chemical structure and biological activity. Am J Kidney Dis 1987;10 Suppl 1:13-23.
100. Veelken R, Delles C, Hilgers KF, Schmieder RE. Outcome survey in unselected hypertensive patients with type 2 diabetes mellitus: effects of ACE inhibition. Am J Hypertens 2001;14:672-8.

101. Ruilope LM. Valsartan and the kidney: review of preclinical and clinical data. Adv Ther 2001;18:5766.

102. Neutel JM. Clinical studies of CS-866, the newest angiotensin II receptor antagonist. Am J Cardiol 2001;87:37-43.

103. Oparil S, Williams D, Chrysant SG, Marbury T, Neutel J. Comparative efficacy of olmesartan, losartan, valsartan, and irbesartan in the control of essential hypertension. J Clin Hypertens 2001;3: 283-91.

104. Biswas PN, Wilton LV, Shakir SW. The safety of valsartan: results of a postmarketing surveillance survey on 12881 patients in England. J Hum Hypertens 2002;16:795-803.

105. Dahlöf B, Devereux RB, Kjeldsen SE, et al. Cardiovascular morbidity and mortality in the Losartan Intervention for endpoint reduction in hypertension study (LIFE): a randomised trial against atenolol. Lancet 2002;359:995-1003.

106. Freytag F, Schelling A, Meinicke T, Deichsel G. Comparison of 26-week efficacy and tolerability of telmisartan and atenolol, in combination with hydrochlorothiazide as required, in the treatment of mild to moderate hypertension: a randomized, multicenter study. Clin Ther 2001;23:108-23.

107. Brogden RN, Heel RC, Speight TM, Avery GS. Metoprolol: a review of its pharmacological properties and therapeutic efficacy in hypertension and angina pectoris. Drugs 1977;14:321-48.

108. Simpson WT. Nature and incidence of unwanted effects with atenolol. Postgrad Med J 1977;53: S162-7.

109. Dunn CJ, Lea AP, Wagstaff AJ. Carvedilol: a reappraisal of its pharmacological properties and therapeutic use in cardiovascular disorders. Drugs 1997; 54:161-85.

110. Lewis RV, Jackson PR, Ramsay LE. Side-effects of beta-blockers assessed using visual analogue scales. Eur J Clin Pharmacol 1985;28:S93-6.

111. Ekbom T, Dahlof B, Hansson L, Lindholm LH, Schersten B, Wester PO. Antihypertensive efficacy and side effects of three beta-blockers and a diuretic in elderly hypertensives: a report from the STOP-Hypertension study. J Hypertens 1992;10:1525-30.

112. Materson BJ, Vlachakis ND, Glasser SP, et al. Influence of beta 2 agonism and beta 1 and beta 2 antagonism on adverse effects and plasma lipoproteins: results of a multicenter comparison of dilevalol and metoprolol. Am J Cardiol 1989;63: 58I-63I. 
113. Feliciano N, Kasarjian H, McMillen JI, et al. Safety and tolerability of metoprolol OROS in hypertension treatment. Am Heart J 1990;120:490-4.

114. LaPalio L, Schork P, Glasser S, Tifft C. Safety and efficacy of metoprolol in the treatment of hypertension in the elderly. J Am Geriatr Soc 1992;40: 354-8.

115. Frewin DB, Lloyd BL, Macdonald GJ, et al. A general-practice study of the efficacy and tolerabil- ity of metoprolol in mild essential hypertension. Med J Aust 1988;148:31-5.

116. Foerster EC, Greminger P, Siegenthaler W, Vetter $\mathrm{H}$, Vetter W. Atenolol versus pindolol: side-effects in hypertension. Eur J Clin Pharmacol 1985;28: S89-91.

117. Streeten DH. Idiopathic edema. Pathogenesis, clinical features, and treatment. Endocrinol Metab Clin North Am 1995;24:531-47. 